\title{
Sociological knowledge and colonial power in Bombay around the First World War
}

\author{
HENRIK C. ASPENGREN*
}

\begin{abstract}
By the turn of the twentieth century a distinct 'social domain'-along with its constituent parts, problems and internal dynamics - was turned into a political entity, and a concern for state bureaucracies existed across the industrializing world. Specific motivations for this trend may have varied from location to location, but included arguments for higher industrial productivity and less political discontent, often intertwined with a humanitarian impulse in calls for better housing, expanded public health or improved working conditions. As has been well documented, the politicization of the social domain in early twentieth-century Britain owes much to the consolidation of British sociology as a distinct discipline. Yet while the link between the rise of social politics and sociology has been established with regard to Britain, little has been said about the occurrence of this coupling elsewhere in the twentiethcentury British Empire. This article aims to rectify that omission by showing the interplay between newly raised social concerns of the colonial administration in the Bombay Presidency, Western British India, and the establishing of sociological research within the borders of the Presidency around the time of the First World War. The article will explore how the colonial administration in Bombay planned to meet new demands for sociological knowledge in colonial state policy, how sociology was subsequently introduced into the Presidency as a research subject, and how new sociological methods were applied in actual colonial government.
\end{abstract}

\section{Sociology and social policy}

The years between the mid-1880s and the outbreak of the First World War were decisive in the formation of 'the social' as a political entity, and as a domain of concern for state action and intervention across the industrializing world. In Britain, it was assertive social liberalism and socialism that most vocally pushed for the making of social politics. Beginning in the late nineteenth century, liberal concepts of 'freedom' and 'progress' came to operate within a new political landscape where various new liberals, reformist Tories and Fabians moved. These political radicals were bound together by a concern that the conditions of modern industrial society might produce obstacles to progress, and create instability. For this heterogeneous group of activists, politicians and thinkers, the social now became the lens through which anxieties over and critiques of industrial

\footnotetext{
* Visiting scholar at the Department of History, Uppsala University, Uppsala, Sweden. Email: h.c.aspengren@gmail.com.

I would like to thank Subir Sinha, Steve Hopgood and the anonymous reviewers of this journal for providing valuable input in the process of completing the article.
} 


\section{4}

Henrik C. Aspengren

capitalism were articulated. ${ }^{1}$ In order to avoid social tension, even class conflict, but also in order to increase productivity and human capacity, official agency must be designed to reach into previously untouched domains of life, and act there, liberals and Fabians now suggested. The intensification of social interventions in Britain by the turn of the twentieth century was closely related to the consolidation of British sociology as a distinct discipline. ${ }^{2}$ Radical politicians or political thinkers found in sociology a scientific approach and a methodology to deal with the growing problems of modern industrial society-problems which they thought begged resolution through political action. Some of these new radicals were themselves professional sociologists, like Leonard T. Hobhouse, or sociologically oriented economists, like John A. Hobson. Others, for example Herbert L. Samuel, claimed political authority through a more-than-average command of sociological knowledge. Whereas the connection between the making of the social as a domain of state action, on the one hand, and sociological methodology and theory, on the other, has been discussed with reference to Britain, very little has been said about how such a connection formed elsewhere in the British Empire of the time. Subsequently, this paper will take the exploration of sociology's link to social governance into the imperial realm. It will do so by asking whether and how sociological methodologies and theories played a role in the formation of tentative social policies in industrializing areas within the British Empire outside the metropole, such as colonial Bombay. This article initially discusses the consolidation of sociology as a distinct discipline in Britain in order to establish, from there, a flow of sociological methods and practitioners that were later taken up in colonial India. The article then goes on to chart sociology's early career in India, and discusses how the colonial administration in the Bombay Presidency drew on sociological theory and methodology, as it began to take the government of the lives of its subjects seriously.

\section{Sociology: a 'science of society'}

'Sociology', explained L.T. Hobhouse in his editorial of the first issue of the quarterly Sociological Review, was nothing less than a 'Science of Society' that connected social knowledge to ethical consideration and political action in innovative ways. ${ }^{3}$ For him, sociological studies produced actionable knowledge, where 'scientific truth is at once translatable into a moral command'. ${ }^{4}$ Or, as Hobhouse's fellow sociologist professor Patrick Geddes pointed out, social survey and social service were closely related. ${ }^{5}$

1 See Peter J. Cain, Hobson and Imperialism: Radicalism, New Liberalism, and Finance 1887-1938, Oxford: Oxford University Press, 2002; Nikolas Rose, Powers of Freedom: Reframing Political Thought, Cambridge: Cambridge University Press, 1999.

2 Stefan Collini, Liberalism and Sociology: L.T. Hobhouse and the Political Argument in England, 1880-1914, Cambridge: Cambridge University Press, 1979.

3 Leonard T. Hobhouse, 'Editorial', Sociological Review (1908) 1(1), p. 3.

4 Hobhouse, op. cit. (3), p. 6.

5 Patrick Geddes, 'Observation and method in sociological studies. Synopsis of a course of lectures for the second term. School of Sociology and Social Economics', 1904, T-GED 3/4/17, University of Strathclyde Archives, Glasgow, p. 1. 
Sociology, as discussed by Hobhouse, had travelled far from its original propositions in the latter half of the nineteenth century. The then strong biological influence on views about human development was being challenged within progressive circles in Britain. The Sociological Society, which was formed in London in 1903, became the platform for turn-of-the-twentieth-century sociology. A wide variety of perspectives were represented within the Sociological Society. For many of the members of the society, as for two of the members with whom we will soon become better familiarized in the Bombay context, Harold H. Mann and Patrick Geddes, on the one hand sociology implied detailed analysis of actual social situations that could enhance the social work of the public and government alike, and on the other hand it could provide facts for grander schematizations of social evolution.

Both Mann and Geddes presented papers during the society's first sessions in 1904. Mann's paper, 'Life in an agricultural village in England', was submitted with the assistance of the sociologist Seebohm Rowntree, whose social survey of York had already become a sociological classic. ${ }^{6}$ Mann's paper was a social-economic study of Ridgmont village, in his native region, Bedfordshire. Mann was inspired by the research approach designed by Rowntree, but also by Charles Booth and his survey of London. Subsequently he outlines in great detail household budgets, rent levels on housing, prices of staple foods, family income, occupations, and percentages of families in poverty. ${ }^{7}$ The inclusion of Mann's paper in the proceedings of the society was awarded some editorial remark. The editorial committee found Mann's paper to embody a 'sociological reorientation of economics'.

The audience was more excited, but a little confused, by papers presented by Professor Patrick Geddes. Geddes was a student of T.H. Huxley. He considered himself an entrepreneur in social sciences and, as such, as Hellen Meller has pointed out, his work is notoriously difficult to pin down. He made a point of being in constant motion, both with regard to subject matter-transgressing academic disciplinary boundaries-and geographically-he travelled almost obsessively. Geddes worked on sociological, botanical, historical, geographical, architectural and educational questions. He wrote between forty and fifty town-planning reports. He worked all over Britain. He worked in Palestine, and both in British India and in several Indian princely states. Social issues, according to Professor Patrick Geddes, must be studied in the multifaceted 'everyday life'. ${ }^{8}$ Accordingly, his experiences of late nineteenth-century urban Britain made him think seriously about urbanization and about what he perceived as the related social problems.

Geddes's first paper before the Sociological Society, 'Civics: as applied sociology', was delivered in July 1904. 9 Sociological studies must be 'concrete' and appeal to 'practical men', argued Geddes in his introduction to the paper. Nonetheless, he ventured on a very abstract exploration of the historic evolution of cities. To understand this process,

6 Harold H. Mann, 'Life in an agricultural village in England', Sociological Papers (1905) 1, pp. 161-193.

7 Mann, op. cit. (6), p. 193.

8 Geddes, op. cit. (5), p. 2.

9 Patrick Geddes, 'Civics: as applied sociology', Sociological Papers (1905) 1, pp. 101-118. 
suggested Geddes, the sociologist must engage both the geography and the history of the city, and combine those into a social and regional survey. Geddes concluded his discussion by outlining forms for civic evolution. In a subsequent paper, read before the society in January 1905, Geddes fleshed out these ideas. The researcher, he argued, should aim to study civics by combining the investigations of the categories of place, work and folk. These categories correspond as social analogies to the biologist's environment, conditions and organism. ${ }^{10}$ Charles Booth, who chaired the session, congratulated Geddes on his 'charming' paper, but emphasized the need for sociologists to engage in 'practical work [which] at the present needs most attention'. ${ }^{11}$ Liberal MP J.M. Robertson joined Booth in his criticism. Robertson argued that sociology would become a dead science if it only dealt with forms and ideal types. Instead, he suggested, sociology must 'grapple with political questions'. A sociologist must always ask, 'How has this inequality of wealth and of service arisen, and how is it prevented in the future?'12 In his third paper presented before the society - 'A suggested plan for a Civic Museum (or Civic Exhibition) and its associated studies'-Geddes further developed his approach and returned to some of the criticism of his previous papers. ${ }^{13}$ This time he focused on trying to theorize everyday realities of cities. ${ }^{14}$ It was the role of the sociologist to construct analytical frameworks for understanding the everyday, he argued. To this end, he asserted, addressing his critics, abstraction was necessary and a mere study of 'concrete family budgets' would not be enough. ${ }^{15}$

\section{Accommodating the official demand for sociology in colonial India}

The development of science and social science in colonial India was always closely connected to the shifting aspirations of British officials and the agendas of the British Raj. Obviously, it is difficult to imagine the official introduction of sociology into British India outside the contemporary parameters set up by the colonial administration of the turn of the twentieth century; social science, as applied in India, formed within contemporary imperial realities. ${ }^{16}$ The relationship between science in general and colonial administrative power was a close one. Deepak Kumar finds science to be inextricably woven into the fabric of colonialism'. ${ }^{17}$

Given Kumar's assertion, the timing of the official introduction of sociological research into British India is significant. Life in industrial areas of India by the turn of the twentieth century was perceived as familiar by colonial administrators; they saw in it a

10 Patrick Geddes, 'Civics: as applied and concrete sociology. Part II'. Sociological Papers (1906) 2, pp. 55-111.

11 Charles Booth, 'Chairman's concluding remarks', Sociological Papers (1905) 1, p. 127.

12 J.M. Robertson, 'Discussion', Sociological Papers (1905) 1, pp. 123-124.

13 Patrick Geddes, 'A suggested plan for a Civic Museum (or Civic Exhibition) and its associated studies', Sociological Papers (1907) 3, pp. 197-230.

14 Geddes, op. cit. (13), p. 198.

15 Geddes, op. cit. (13), p. 215.

16 Gyan Prakash, Another Reason: Science and the Imagination of Modern India, Princeton, NJ: Princeton University Press, 1999.

17 Deepak Kumar, Science and the Raj 1857-1905, Delhi: Oxford University Press, 1997, pp. 3, 15. 
mirror image of the past experience of Europe: urbanization, industrialization, and class segmentation. Born out of that sense of shared experience emerged ideas of employing similar-yet not the same-social interventionist designs used in Britain at the time. Moreover, the first decades of the twentieth century would prove to be politically troubled times in India for the British, and so projects of housing, sanitation and primary education were elaborated in order both to ameliorate deteriorating social conditions and raise productivity, and to stabilize local populations. The Bombay Presidency, with its expanding textile industries, large workforces and growing lower middle class, was, as I have shown elsewhere, a case in point. ${ }^{18}$ Clearly, from the perspective of the Government of Bombay, and that of Bombay's industrialists, social realities in urban industrial India begged serious investigation. Subsequently, in order to come to know conditions of life in modern industrial India, the colonial administration in Bombay began to dwell on how to establish sociological research in the Presidency and how to utilize sociological methods in government.

At the time of Harold H. Mann's and Patrick Geddes's productive roles at the inception of the Sociological Society, their respective work was taken up in India and, in particular, in the Bombay Presidency. Soon after he presented during the first sessions of the Sociological Society in London, Harold H. Mann took up a position as principal of the agricultural unit in Poona, Bombay Presidency. As will be further discussed below, Mann played a significant role in the expansion of the University of Bombay and in the establishment of a School of Economics and Sociology at the university. Moreover, as we shall see, Mann himself carried out or assisted in new sociological studies in the Presidency.

Patrick Geddes had been active in promoting sociology in India for some time, and he attached his effort to the highly anticipated proposal for a research institute by J.N. Tata. ${ }^{19}$ In 1901, Geddes wrote Tata open letters outlining what he called a 'needed type of research institute, geographical and social'. Geddes's letters were printed in two Indian publications, the Pioneer in August 1901, and East and West in September 1903. In his articles, Geddes suggested an integrated institute, focusing on civics, which centred the social and geographical 'regional survey' as its main feature. ${ }^{20}$ The knowledge coming out of such an institute would be beneficial for government as well as for the general public, Patrick Geddes asserted.

Geddes's plans were not successful with Tata. His proposals had, however, ignited the interest of local officials elsewhere in British India. Hopes of studying urban social questions in an Indian context were nourished by sections of colonial administrators. For them, sociology brought with it concrete methods for studying modern life, yet it could be sensitive to various local forces, of which progress was contingent. Within this context, ideas about establishing sociology as a university subject were floated in Bombay.

18 Henrik C. Aspengren, 'Empire: a question of hearts? The social turn in colonial government, Bombay c. 1905-25', in Mark Duffield and Vernon Hewitt (eds.), Empire, Development, and Colonialism: The Past in the Present, London: James Currey, 2009, pp. 45-58.

19 This exchange thus pre-dated Geddes's more celebrated correspondence with novelist and educationalist Rabindranath Tagore, and pioneering scientist J.C. Bose.

20 Patrick Geddes, 'On universities in Europe and in India and a needed type of research institute, geographical and social', Five Letters to an Indian Friend, Madras, 1903. 
Yet establishing sociological research in Bombay would turn out to be an urgent but slow process. In response to the question about the utilization of grants put forward by the Government of Bombay in 1912, the University of Bombay appointed a committee. ${ }^{21}$ The committee met from June to August to outline a scheme of how best to put the grants into work. The committee consisted of members of the Bombay University Senate, members of the Legislative Council, and local businessmen. The University of Bombay had the doubtful privilege of having an active, but quite autocratic, chancellor in the former governor of the Presidency, S.G. Clarke, later Lord Sydenham of Combe. ${ }^{22}$ In fact, much of the stipulated committee's work was preempted by Clarke as he widely circulated a letter addressed to the university vicechancellor, formulating his view on how the grants ought to be put to use.

In his letter, Clarke argued that the grants open up 'new possibilities of the greatest importance to the Presidency'. ${ }^{23}$ If utilized well, Bombay University could significantly strengthen its position as a centre of learning, and also widen its scope. There were also new opportunities for the university to focus on primarily social, economic and historical studies, and subsequently contribute to the running of the Presidency. 'A living university', Clarke writes, 'should not concern itself with its students alone. It should be an intellectual force in the State'. ${ }^{24}$

In its final report, the committee was left with little choice but basically to adopt the outline made by Clarke. The committee recommended that one or more 'eminent' professors or lecturers should be brought annually from Great Britain to deliver lectures in Bombay over a wide range of topics in economics, sociology and history. ${ }^{25}$

In a simultaneous but separate exchange between Bombay and Delhi, the Government of Bombay discussed whether to establish a commercial college in the Presidency. A commercial college, the Government of Bombay argued, 'must be under Government control' but would consult with an advisory board where the commercial interests of Bombay would be represented. ${ }^{26}$

Shortly after hearing out the Government of Bombay on the two separate issues of the grants for the university and the establishment of a commercial college, the Government of India published its Educational Policy of 1913. In it, Delhi now found that due to the expansion of interest in commercial education in British India, it would be worth

21 Maharashtra State Archives, Mumbai, F. Dastur to secretary of Government of Bombay Education Department, 5 September 1912, letter no. 2195, Government of Bombay Education Department Compilation 360 of 1914.

22 A. Ganachari, 'Imperial appropriation and disciplining the Indian mind (1857-1917): whose history?', Economic and Political Weekly, 2 February 2008, pp. 77-88.

23 Maharashtra State Archives, Mumbai, Chancellor, University of Bombay, to Vice-Chancellor, University of Bombay, 4 July 1912, Government of Bombay Education Department Compilation 360 of 1914.

24 Maharashtra State Archives, Mumbai, Chancellor, University of Bombay, to Vice-Chancellor, University of Bombay, 4 July 1912, Government of Bombay Education Department Compilation 360 of 1914.

25 Maharashtra State Archives, Mumbai, University of Bombay, 'Report of the committee of the syndicate appointed to consider proposals of the utilization of the government grants and the letter of government regarding the contribution by the university towards the cost of the examination halls', 1912, Government of Bombay Education Department Compilation 360 of 1912, p. 1.

26 Maharashtra State Archives, Mumbai, Government of Bombay, Resolution no. 888 E. D., 3 April 1912, Government of Bombay Education Department Compilation 360 of 1914. 
considering 'the question of making arrangements for organised study of the economic and allied sociological problems of India'. For the first time the Government actually combined the topics of economics and sociology into one distinct field of knowledge requiring an institutional home, and in that context it put forward Bombay as the place best suited for hosting such an institution.

The idea of a college of commerce that included sociology in its syllabus met ready response in Bombay. Building on that response, the Government of India suggested that

Indian sociology or Indian history treated from the sociological point of view is a science to which little or no attention has hitherto been given ... The aim of a sociological history of India would be to arrive at the conditions which made the politics, the religion and the general structure of Indian society in its distinctive features. ${ }^{27}$

By synthesizing ethnographical, sociological, historical and economic 'facts', keen observers of Indian conditions might derive a better understanding of contemporary Indian social, political and commercial life, the Government of India suggested. ${ }^{28}$

While the Governments of India and Bombay discussed the establishment of a sociological connection to the proposed college, the University Senate now attempted to wrestle control over sociological research in its favour. In its new scheme for postgraduate studies the Senate outlined four departments of teaching and research. Among those four, one department was to combine the study of 'Sociology and Economics'. ${ }^{29}$ Subsequently, the Government of Bombay noted that it was now under consideration whether it would be more advantageous to create a 'School of Indian Economics and Sociology', and place it under the management of the University of Bombay. ${ }^{30}$ Both the Government of India and Government of Bombay agreed to this new set-up in August 1914. The cost of two professorships in Bombay, one in sociology and one in economics, was sanctioned with effect from the 1915-1916 financial year.

The First World War put the planned expanded teaching in sociology on hold. Yet the interest in the new forms of applied sociology was not reduced by the war within the wide circles of government in Bombay. Harold Hart Mann, now fellow of the university and increasingly connected with the Government of Bombay, was in touch with Patrick Geddes through their affiliation with the Sociological Society in London. Mann nourished hopes of bringing Geddes to Bombay, in order to help establish sociological research there.

In 1914 Lord Pentland, the then governor of the Madras Presidency, invited Geddes to Madras. Geddes, as well as Pentland, hoped other 'liberal' governors would take interest

27 Maharashtra State Archives, Mumbai, H. Sharp to secretary, Government of Bombay Education Department, 27 May 1913, letter no. 951, Government of Bombay Education Department Compilation 360 of 1914.

28 Maharashtra State Archives, Mumbai, Government of India, 21 February 1913, Resolution of Government of India, Education Department no. 301-C. D. [paragraph 43], Government of Bombay Education Department Compilation 360 of 1913.

29 Maharashtra State Archives, Mumbai, University of Bombay, 'Scheme prepared by the Syndicate for the development of university postgraduate studies, 2 Aug 1913', Government of Bombay Education Department Compilation 360 of 1913, p. 1.

30 Maharashtra State Archives, Mumbai, Government of Bombay, Departmental note, 22 January 1914, Government of Bombay Education Department Compilation 360 of 1914. 
in his work. Most of Geddes's initial work in India was practical and his reports were published as official publications. ${ }^{31}$ This might have restricted his audience. In the pages of the Sociological Review, however, his reports were praised for their applicability and “"concrete" sociological method', thus their translatability into planning and actual policy in India. ${ }^{32}$ Geddes found interested administrators in the industrializing Bombay Presidency, as well as in Calcutta, but was not able to influence administrators all over British India. For many he seemed too radical. Geddes insisted that modern urban social questions demanded new administrative and political approaches in order to be resolved. According to Meller, Geddes even thought that 'it would be possible to bypass some of the stages of change suffered by western cities under the impact of industrialisation'. ${ }^{33}$

H.H. Mann wrote to Patrick Geddes in November 1914 suggesting that he come to Bombay for a longer stretch of time. There was so much to do for a sociologist in India, Mann indicated. ${ }^{34}$ As Geddes's European tour with a portable exhibition on 'Cities and town planning' had been compromised by the war, he decided to travel to Bombay with the exhibition. The exhibition and accompanying lectures - with the main theme of 'citizenship' - were welcomed as important contributions to ongoing debates about civics, rights and urban governance in Bombay. ${ }^{35}$

After leaving Bombay in 1915, Geddes kept in contact with local administrators. S.M. Edwardes, who would later take charge over the Bombay Police, was one of them. It was to him that Geddes suggested the need to set up a 'civic institute' in Bombay. Edwardes welcomed this idea. From his sick leave in London, he endorsed it as 'very sound'. And, wrote Edwardes, 'although in Bombay we are only in the beginning to think of grappling with the various problems, social, sanitary, economic etc. which arise in every urban area', the main problem was still 'lack of coordination and little exchange of experience between the various bodies or organisations that are at work'. ${ }^{36}$

Edwardes's answer to Geddes reflected a growing hope nourished by officials in Bombay to find an institutional structure for the exchange and accumulation of knowledge about social conditions. Unrest added urgency to that administrative preoccupation. The outbreak of war had produced a sharp rise in prices of staple goods in urban India. Rising prices caused hardship among the Indian population. Moreover, after a period of slow consolidation Indian nationalists now began to broaden their

31 See, for example, Patrick Geddes's Reports on the Towns in the Madras Presidency Visited by Professor Geddes 1914-15, Madras: Government Press, 1915; but also Town Planning Reports for Balrampur, Baroda, Dacca, Kanchrapara, Jubbulpore, Karputhala, Lahore, Lucknow and Nagpur. All published during the period 1915-17. See also Geddes's Town Planning towards City Development: A Report to the Durbar of Indore, 2 vols., Indore: Holkar State Printing Press, 1918.

32 Alexander Farquharson, 'An Indian example', Sociological Review (1919), 11(1), pp. 65-68.

33 Hellen Meller, Patrick Geddes: Social Evolutionist and City Planner, London: Routledge, 1990, p. 203.

34 University of Strathclyde Archives, Glasgow, T-GED 12/3/42, Harold H. Mann to Patrick Geddes, 24 November 1914.

35 Sandip Hazareesingh, 'The quest for urban citizenship: civic rights, public opinion and colonial resistance in early twentieth-century Bombay', Modern Asian Studies (2000) 34, pp. 797-829, p. 805.

36 University of Strathclyde Archives, Glasgow, T-GED 12/3/54, S.M. Edwardes to Patrick Geddes, 30 November 1916. 
appeal in various sections of society. Increasingly assertive nationalism managed to tap into growing discontent within business elites, as well as within large sections of the peasantry and the urban lower and middle classes.

Furthermore, in Bombay a semi-autonomous workers' politics was in the making. The First World War had brought great fortunes to Bombay manufacturers. Increased profits coincided with the general price rise, and demands were being made for higher wages. Before 1914, strikes had occurred within the cotton mill industry, although with little coordination between the various sections of workers on strike. Around 1917 and 1918 that would begin to change, and between 1919 and 1940 eight well-coordinated general strikes were carried out in Bombay.

The general strike in Bombay in 1919 and 1920 involved 200,000 people and lasted several months, and had the backing of a sustainable organization and networks reaching out to surrounding villages in the Presidency. ${ }^{37}$ At the base of the strikes lay demands for higher wages and an end to wage cuts. However, Sumit Sarkar argues, the formation of mass workers' politics in the larger industrial towns in British India could not be explained by economic hardship alone: there was a general political awakening among workers and peasants throughout the industrializing world at this time. ${ }^{38}$ Also of significance for the situation in Bombay was the start of the all-India non-cooperation movement in 1919 under the leadership of M.K. Gandhi, and Shaukat and Muhammad Ali. The situation caused much anxiety among British officials, who had little idea of what was going on in workplaces and poorer neighbourhoods. Edwin Samuel Montagu, then Secretary of State for India, involved in the peace negotiations at Versailles, wrote worried letters from Paris to the then governor of Bombay, George Lloyd, suggesting that Montagu should perhaps convince the socialist and trade unionist John Burns to go to Bombay and organize the workers properly. ${ }^{39}$

Simultaneously, by the end of the First World War the field of sociology had become central to the new scheme for the expansion of higher education within the University of Bombay. Sociology was no longer attached as a contingent to commerce as an 'allied subject' - it was understood as valuable knowledge in its own right. Due to the substantial changes to the original proposal from the University of Bombay from 1912-1913, a new approach was called for from the University Senate.

Subsequently, Harold H. Mann drafted an outline of a proposed 'school of economics and sociology'. Mann's outline, which later was adopted by a University of Bombay committee, suggested that the purpose of the school should 'definitely be to give the opportunity to students to conduct research in economics and sociology'. ${ }^{40}$ Mann

37 R. Bakshi, The Long Haul: The Bombay Textile Workers' Strike, Bombay: BUILD Documentation Centre, 1986.

38 Sumit Sarkar, Modern India 1885-1947 (1983), London: Macmillan, 2005, pp. 176-177.

39 Edwin Montagu to George Lloyd, 29 January 1919, collection 22, Montagu Papers, Mss Eur D523, Oriental and India Office Collection, London; Edwin Montagu to George Lloyd, 8 April 1920, collection 22, Montagu Papers, Mss Eur D523, Oriental and India Office Collection, London.

40 University of Strathclyde Archives, Glasgow University of Bombay, T-GED 9/1384.2, 'Scheme prepared by the Syndicate for proposed school of economics and sociology, 20 February 1917'. 
forwarded his outline to Geddes in May the same year, hoping he could soon come to Bombay again and perhaps take charge of the school. ${ }^{41}$

With the increasing official demand for sociological knowledge followed calls for stricter governmental control over future research. Selby, the Bombay Government's Director of Public Instruction, argued in a response to Mann's outline that the Government of Bombay must now make it clear that any appointments of professors, assistant professors, or secretary to the new school would have to be sanctioned by the Government. The nature of the subjects researched by the school, and 'their connection with important and far-reaching political and administrative problems', motivated infringements in academic freedom, Selby argued. ${ }^{42}$ Subject to minor changes, the governor of Bombay approved the revised scheme in August 1918. Mann had suggested that Patrick Geddes be appointed professor of sociology in Bombay, and Percy Anstey, the principal of the university, moved for the appointment of Geddes with effect from 1 August 1919 in the University Senate. ${ }^{43}$

Before long, however, Patrick Geddes was being increasingly marginalized in Bombay. He left Bombay in 1924 without managing to alter how his approach to sociology was viewed. Neither the Government of Bombay nor the business community would assess his tenure as a success. There are few concrete examples that prove his influence over individuals or institutional structures. Geddes's initial hopes to engage students and to conduct wide surveys of the city and region were never fulfilled. ${ }^{44}$ Yet during his tenure as professor of sociology, Geddes had begun to stress the importance of greater official involvement in social problems. He elaborated on the necessity for the Government of Bombay to act upon deteriorating social conditions in order to temper growing urban unrest, and he outlined ways in which research emanating from the sociological branch of the University of Bombay could inform policy. Urban housing was one such social policy area in which the Government must be more involved, Geddes argued. For Geddes, poor housing in Bombay City manifested urban poverty in an obscene way, and finding its remedy might help reverse emerging revolutionary tendencies.

In this connection, Geddes suggested a committee of officials and non-officials that would enable the integration of the work of the University of Bombay into wider society. He tried to channel the sociological approach elaborated in his classes towards the new schemes of the Bombay Development Department - a department of the Government of Bombay designed to deal with issues of housing and town planning. ${ }^{45}$ However, due to Geddes's frequent engagements elsewhere, the committee, in fact, rarely met.

41 University of Strathclyde Archives, Glasgow, T-GED 9/1438, Harold. H. Mann to Patrick Geddes, 2 May 1919.

42 Maharashtra State Archives, Mumbai, Government of Bombay, Government unofficial note no. M-79, 13 May 1918, E. D. Compilation 360 of 1918.

43 University of Strathclyde Archives, Glasgow, T-GED 9/1456, Percey Anstey to Patrick Geddes, 24 July 1919.

44 Meller, op. cit. (33), p. 223.

45 University of Strathclyde Archives, Glasgow, T-GED 12/1/208, F. Dastur, 'The Committee on Collaboration between the Bombay University and the Bombay City. Agenda of the meeting of the committee 9 February 1923'. 
While administrators and public figures were marginalizing his abstract form of sociology, Geddes took to satire in his critique of housing conditions in Bombay. His piece 'University of Bolshevism (established 1920) in Worli Bombay' was an attempt to describe ironically the ways in which poor housing conditions in Bombay paved the way for bolshevism, and how the Government of Bombay, through its own previous policies, promoted revolutionary activity as effectively as any agitator or conspiracy. In his satire, Geddes describes how the 'University of Bolshevism' had been open for three years, in order to promote bolshevism in India. ${ }^{46}$ The 'university' had so far been able to appeal to the 'dissatisfied workers in the city', but was set to recruit from almost all classes in the city of Bombay. The main work of the 'university staff' was to bring about dissatisfaction among those enrolled. The university had accomplished its work better than similar institutions in Russia or Germany, Geddes wrote wryly. Overcrowded housing with small rooms with little light and air catered for its success. Added to this was high rent, insufficient lighting and no parks or playgrounds. Here, Geddes wrote, lay the path to radicalization of the population in Bombay.

In the latter part of Geddes's tenure, influential Bombay citizens began to question the work of the whole School of Economics and Sociology. Two influential men of business in Bombay, P.A. Wadia and Lakshmidas Raowjee Tairsee, wrote to the Times of India and to the Bombay Chronicle respectively and complained of the impractability of Geddes's approach to sociology and the lack of tangible outcome of the school. ${ }^{47}$ Both critics found it difficult to see exactly how Geddes's schemes of social evolution or his vision of Bombay University as a node in the economic and social life of Bombay would contribute to the Presidency's coming to terms with its increasing social problems. By citing concepts employed by Geddes in his teaching, such as 'bio-technics' and 'ethopolity', and calling them 'aloof', Wadia put before the readers a call for a more concrete application of sociological methodology. The Government of Bombay worried about these views. It wrote to the university and requested a full report on the school and its work. ${ }^{48}$ However, the contention was perhaps not so much with Geddes, as with the abstract and theoretical sociology he represented. Geddes's marginalization reflects the ways in which abstract sociology was perceived to have no place within a colonial context.

\section{Applied sociology in colonial government}

However, the demand for sociological knowledge in colonial government could be met in more direct ways than through academic research. A form of 'applied' sociology found favour with the colonial administration. Applied sociology made it possible for the colonial administration to utilize sociological methods in very narrow and policyoriented ways when attempting to comprehend social conditions in the Presidency.

46 University of Strathclyde Archives, T-GED 12/1/282, Glasgow Patrick Geddes, 'University of Bolshevism (established in 1920) Worli Bombay', n.d. (1920?).

47 P.A. Wadia, 'Readers views' - Bombay University - post graduate studies', Times of India, 14 September 1923. L. Raowjee Tairsee, 'School of Sociology and Economics', Bombay Chronicle, 25 April 1923.

48 University of Strathclyde Archives, Glasgow, T-GED 12/3/63/6, Ziman to F. Dastur, 25 May 1923. 
Of course, there were plenty of data on social problems in the Bombay Presidency to be found in late nineteenth-century official records. But with the increasing social interest of the colonial state, and the urgent need to grasp social realities in colonial India, applied sociology began to influence how the colonial administration collected data and accumulated knowledge.

Beginning in 1871, the Census became a central tool in mapping the whereabouts of the subjects of the Raj, and the conditions under which they lived. Every tenth year a new census would be conducted on an all-India level. The censuses painted with broad strokes various aspects of life and society in colonial India. Local colonial administrations also gathered and published information through Local and District Gazetteers. These were complemented by the Imperial Gazetteer, which first appeared in 1881 . Actual 'surveys' were initially conducted with military objectives. During the 1880s and 1890s, however, Kumar points out, 50 per cent of those employed to carry out government surveys were working with surveys carried out for revenue purposes. ${ }^{49}$ The focus on revenue enhancement did not reduce the political dimensions of the survey. David Arnold suggests that surveys 'subordinated science to an ultimately political understanding of India and an administrator's sense of what constituted necessary knowledge'.50

If surveys and censuses were main sources of social knowledge, there were plenty of other sources as well. Municipal health and sanitation officers produced detailed statistics on rates of birth and death, police records describe riots from various points of view, and departmental annual reports and returns speak of conditions under which people lived and laboured. Campaigns against malaria, famine relief, flooding assistance and other particular interventions were followed by report-producing committees and commissions, where each and every report includes a wealth of information about conditions of life.

During the first decades of the twentieth century, however, a new style of reporting on conditions of life emerged. This form of reporting investigated social problems in themselves - that is, exactly in their capacity of being 'social'. This reporting was not contingent on, or an extension of, investigations into natural calamities or disease. It looked into a new terrain of human existence, a new dimension of life: the social for its own sake. This form of social reporting takes its cue explicitly from contemporary sociological method; it refers to those methods and places itself within a longer tradition of social studies. The social survey attempted to investigate a wide range of social issues - for example housing, education and sanitation - simultaneously and in a holistic manner. For the first time, British colonial administrators and their Indian colleagues began to report on social issues placed within a distinct and integrated social space. The reports on social issues followed, at this time, a certain pattern of almost standardized tabulations and inclusion of ethnographic detail. Household budgets, debt levels, conditions of housing, food prices and family income-all packaged along with descriptions of the home and work lives of workers and the middle classes. And here,

49 Kumar, op. cit. (17), p. 75.

50 David Arnold, Science, Technology and Medicine in Colonial India, Cambridge: Cambridge University Press, 2000, p. 131. 
within this compiled data of social-economic relations, officials claimed, lay the prospect of welfare and progress, and the risk of discontent.

The scope of the 'social survey' conducted by Arthur Edward Mirams, consultant surveyor to the Government of Bombay, on behalf of the Indian Industrial Commission, was wide. It covered almost all aspects of life in an industrial city. Mirams followed the format of similar studies made in industrial Britain. He submitted his memorandum and was called to give oral evidence in late November 1917, when the Commission stopped over in Bombay. While Mirams's oral evidence concentrated on the issue of housing of workers, which he most 'emphatically' found the most important area of reform, his written evidence was more comprehensive. ${ }^{51}$

For Mirams the 'improvement of industry' was intertwined with the 'improvement of labour'. For industry to develop, he asserted, the wage-earning classes had also to develop socially. However, Mirams was at pains to suggest that the 'improvement of the employee for his own sake' is a 'highly important' topic in itself. Although Mirams explicitly hoped that sociologists, as well as local authorities, would investigate further the matters brought up in his survey, his is an account narrating the social conditions of the city through methods of contemporary sociologists.

A.E. Mirams used his social survey to argue that solving social problems would increase the industrial output of the population, enhance progress and stabilize neighbourhoods and social structures. He was not alone in his assumptions; they were shared by officials and influential sections of public opinion alike. Several mill owners who were called to witness before the Indian Industrial Commission made a case for social management by the state. They argued that, for example, the use of public expenditure towards better housing would keep workers at home rather than hanging out on the streets after work; others suggested that the rise of Japan as an industrial nation was caused by how Japan had managed to reform its system of education. ${ }^{52}$

Indeed, Mirams wrote in order to convince his colleagues in the Bombay Presidency and members of the Industrial Commission that contemporary social conditions had an undeniable effect on the population. The survey neatly played into administrators' growing anxiety about the future industrial progress of the Presidency. As officials better came to know the conditions under which workers, artisans and also the lower middle classes lived their lives outside the factories, they began to argue that living conditions slowed industrial progress. Were these conditions not ameliorated, then other reforms to increase industrial productivity would have no real impact. ${ }^{53}$ In fact, it was suggested that with the continuation of present conditions of living, other reforms could become counterproductive. Mirams, on his part, hoped that his study would help 'emphasise ... the correlation of Housing, Education and Recreation'. ${ }^{44}$ It seemed to him that

51 Government of India, 'Oral evidence by Mirams, A.E., 23 November 1917', in Report of the Indian Industrial Commission, Calcutta, 1918, p. 369.

52 Government of India, Report of the Indian Industrial Commission, with Evidence, Calcutta, 1918.

53 Maharashtra State Archives, Mumbai, Government of India, 'Thomas Holland proceedings of 19 February 1920', Proceedings of the Indian Legislative Council of 1920, 1920, p. 817.

54 A.E. Mirams, 'Memorandum', in Report of the Indian Industrial Commission, with Evidence, Calcutta, 1918, p. 19. 
various social issues were clearly interlinked, and must be presented within the same investigation.

A couple of years after Mirams submitted his memorandum, Harold Hart Mann wrote his report of the Sakchi industrial estate in Jamshedpur, where Tata had set up an expanding iron and steel enterprise. Mann had been called upon to lead a survey of the social conditions and social welfare provisions in this expanding industrial town. He arrived in late September 1918 and stayed for one and a half months. At the time of his arrival, Sakchi had grown out of proportion, Mann pointed out. Amenities and infrastructure on the industrial estate had originally been developed for a population of around twenty thousand people. In 1918, a decade after its inception, more than a hundred thousand were dependent on the works of the estate, or its dependencies. Mann, whom we saw earlier had been involved in the work of Seebohm Rowntree and was later involved in the Sociological Society, maintained the same sociological methodology.

In his study of Sakchi, Mann covered a similarly wide range of social topics as Mirams had done in his memorandum submitted to the Industrial Commission. Mann brought to the survey his intimate knowledge of conditions in Bombay, and his keen sociological interest. His final Report on the Investigations with Regard to Social Welfare Work at Jamshedpur was included in the Jamshedpur Social Welfare Series, along with a detailed report on town planning. ${ }^{55}$ In the report, Mann describes in great detail the existing social provisions at the Sakchi industrial estate. He also gives recommendations regarding how a social welfare organisation could be further developed, in order to secure that the estate shapes into one 'where a healthy, decent, happy, and contented population can continue to exist'. ${ }^{56}$ As was Mirams's, Mann's study was firmly placed within an emerging tradition of social surveys. It heavily drew on contemporary sociological methods, as well as categorizations.

The study investigated household budgets for various groups working in Sakchi. Mann meticulously listed food items and their prices, and amended quantity and expenditure according to ethnicity and occupation. An 'Aboriginal Coolie' and his family, a 'United Provinces Hindu', or 'Bengalis of the Artisan Class', all had their budgets broken down and analysed. Mann discussed the drinking habits of various sections of the inhabitants under the heading 'Moral tone of the town'. He then discussed health facilities, facilities for women and children, 'Social welfare in the works', education levels, housing conditions, public amenities - in short, almost all areas conceived of as important dimensions of social life were studied and followed up for conclusions.

Indeed, Mann found that even questions about sewage, sewage disposal and the supply of goods to the town had to be considered 'from the social point of view'. ${ }^{57}$ An industrial town like the Sakchi estate must continuously be monitored from a

55 Harold H. Mann, Report on the Investigations with Regard to Social Welfare Work at Jamshedpur, Poona, 1919.

56 Mann, op. cit. (55), p. 2.

57 Mann, op. cit. (55), p. 1. 
sociological perspective, Mann asserted. A future social welfare organization, he mentioned, should include 'social workers' contributing to the welfare of the population. Such social workers would enable future welfare provisions by carrying out 'actual careful scientific inquiries' into conditions of work and leisure. ${ }^{58}$

Between his article in Sociological Papers and his study of Sakchi, Mann had spent more than fifteen years within the wider circles of colonial government in Bombay. Yet clearly he was consistent in his way of conducting social surveys. He, along with others within the governing circles, saw the benefit of including sociology into governmental practice.

This approach was further entrenched and applied on a wider scale through the establishment of the Government of Bombay Labour Office. The Labour Office, under G. Findlay Shirras - former director of statistics with the Government of India - carried out almost yearly studies into social and economic conditions of the Presidency from the early 1920s. In the radicalized climate in Bombay after the First World War, the Labour Office began studying a wide range of aspects of the lives of workers in different sectors, artisans and the middle classes.

Under Shirras's leadership, the Bombay Labour Office began with studies of wages and working hours of those employed in the cotton mill industry. The impulse to carry out those studies came from the mill owners, as well as from the Government of Bombay. The studies provided by the Bombay Labour Office helped industrialists keep track of demands on wage levels. Studies into the lives of sections of colonial society helped the Government as well, in its attempts to grasp the conditions of workers and the middle classes. ${ }^{59}$ Harold Mann himself later collaborated with the Labour Office in a study of wages within the agriculture sector in the Presidency. The study was ambitious in that it attempted to cover the annual changes in agricultural wages over two decades. Shirras explained how he had been reminded by members of the legislative Council in Bombay that the International Labour Office collected data on labourers within the agricultural sector, and the Imperial Statistical Conference had called attention to that issue as well. ${ }^{60}$ Although Shirras carefully attended to ethnographic detail, the organizing categories used in the study were strictly social-economic and occupational.

Shirras and the Labour Office also published reports looking into working-class family budgets in Bombay City, where statistics were compiled to describe general social conditions of various sections of the labour force. The study was a success among influential circles in Bombay, and it was decided in 1923 to follow it up with an enquiry into 'sociological and economic' subjects concerning the middle classes. ${ }^{61}$ By the late 1920s, the Labour Office began probing into working- and middle-class unemployment. The timing of the inception of research under the Bombay Labour Office was significant.

58 Mann, op. cit. (55), p. 93.

59 G. Finlay Shirras, Report on an Enquiry into the Wages and Hours of Labour in the Cotton Mill Industry, Bombay, 1923, p. 1.

60 G. Finlay Shirras, Report on an Enquiry into Agricultural Wages in the Bombay Presidency, Bombay, 1924 , p. 1.

61 Maharashtra State Archives, Mumbai, Government of Bombay Labour Office, 'Report on an enquiry into the middle class family budgets in Bombay City, 1924', F. D. File 5781 (ii) of 1927. 
The Labour Office began to submit its information to the Government of Bombay and the Government of India, as well as to the International Labour Office, at a period of growing industrial unrest. The investigations conducted by the Labour Office depicted the ways in which workers and the middle classes lived their lives. For the Government of Bombay, this was valuable information. The radicalization of the post-war environment made it important for the administration to understand what moved the working and middle classes.

\section{Conclusion}

In this article I have discussed the relationship between sociology and colonial power in the Bombay Presidency around the First World War. I suggested that just as early twentieth-century social policy in Britain was influenced by British sociology, there existed, at this time, a similar close connection between sociology and colonial government. In this article I have described the particular ways in which the colonial administration in the Bombay Presidency met its newly awoken demands for social knowledge for its attempts to manage social problems in colonial society.

I used the debate surrounding the establishment of a school of economics and sociology in Bombay to exemplify the growing interest in the discipline of sociology among colonial officials. Officials hoped to establish a department of sociology where actual research into sociological questions could be conducted, which would, in turn, help them come to know the issues that mobilized urban Indian society. Yet, I pointed out, social science in a colonial situation acted within strict confines. Social science, I suggested, was always measured against its utility for government. So, while the University of Bombay finally recruited the well-known professor Patrick Geddes, who had been an active voice in the formation of sociology in Britain, his sociology did not fit the colonial foot. Colonial administrators and local business elites looked for a practical form of sociology that could generate data of contemporary social conditions. Ultimately, the colonial administration only had use for sociology in its applied form and Geddes was marginalized and criticized for his abstract sociology. Yet he made efforts to elaborate ways in which social knowledge could benefit business, people and government. Geddes also drew attention to the forms of radicalism and unrest that might come out of a continued lack of attention to social problems in the midst of urban life.

The ways in which early twentieth-century applied sociology helped both to delineate and to reveal the social as a domain in need of management, and turn it into an area of administrative concern, were unprecedented in Bombay. Social surveys, this new way of reporting on the conditions of life, and the social as a political space proved their utility to the colonial administration. Reinscribing the traditional survey into the social domain helped administrators to come to know that domain, partly in new ways. As the social domain grew in political importance, so did the command of methods to study it. Sociology, in its applied form, produced a kind of action-oriented knowledge colonial administrators thought they needed when dealing with the new realities they were facing. 